\title{
Morphometric study of the fibrosis and mast cell count in the circular colon musculature of chronic Chagas patients with and without megacolon
}

\author{
Estudo morfométrico da fibrose e do número de mastócitos na muscular \\ circular do cólon de chagásicos crônicos com e sem megacólon \\ Simone Wanderley Pinheiro', Adilha Misson de Oliveira Rua', Renata Margarida Etchebehere', \\ Cristiane Gobbo Cançado', Javier Emílio Lazo Chica', \\ Edison Reis Lopes ${ }^{1}$ e Sheila Jorge Adad'
}

\begin{abstract}
A morphometric study of the circular colon musculature was performed, in which the mast cell count was determined and the connective fibrous tissue in this layer was measured. The objective was to gain better understanding of Chagas megacolon morphology and contribute towards the knowledge of fibrosis pathogenesis in Chagas megas. An evaluation was made of 15 distal sigmoid rings from Chagas patients with megacolon (MCC), 15 without megacolon (CSMC) and 15 non-Chagas patients (NC). The rings were fixed in formol, embedded in paraffin, and $7 \mathrm{~mm}$ thick sections were cut and stained using Azan-Heidenhain and Giemsa. The mast cell count and fibrosis were greater in the MCC group than in the CSMC and NC groups $(p<0.05 ;$ Kruskal-Wallis test) and there was no significant difference between the latter two. The fibrosis and increased mast cell count in the colon musculature of the MCC group possibly indicates that there is a relationship between mastocytosis and fibrosis, as has already been demonstrated in other pathologies.
\end{abstract}

Key-words: Megacolon. Mast cell. Fibrosis. Morphometry. Chagas'disease.

Resumo Com os objetivos de conhecer melhor a morfologia do megacólon chagásico e contribuir para o conhecimento da patogênese da fibrose dos megas, realizou-se estudo morfométrico na muscular circular do cólon, contando-se o número de mastócitos e medindo o conjuntivo fibroso nessa camada. Foram avaliados anéis do sigmóide distal de 15 chagásicos com megacólon (MCC), 15 sem megacólon (CSMC) e 15 não chagásicos (NC). Os anéis foram fixados em formol, incluídos em parafina, cortados com $7 \mathrm{~mm}$ de espessura e corados por Azan-Heidenhain e Giemsa. O número de mastócitos e a fibrose foram maiores no grupo com MCC em relação ao CSMC e NC ( $p<0,05$; teste de Kruskal-Wallis); não houve diferença significante entre os dois últimos grupos. Diante destes achados, é possível, que haja relação entre mastocitose e fibrose no megacólon chagásico, como já se demonstrou em outras doenças.

Palavras-chaves: Megacólon. Mastócito. Fibrose. Morfometria. Doença de Chagas.

Muscle layer alterations such as myositis and fibrosis that could contribute to the pathogenesis of Chagas' disease megas are often found both in the esophagus ${ }^{1316}$ and in the colon ${ }^{216}$. According to Tafuri and Raso ${ }^{16}$, fibrosis in Chagas megaesophagus sometimes is focal, possibly representing a sequel of myositis and thought to be associated with mast cell infiltrate, and sometimes is diffuse and interstitial without showing a topographic relationship with the inflammation. Andrade \& Andrade ${ }^{8}$, analyzing myocardial fibrosis, also accepted that focal fibrosis could result from scarring of inflammatory foci related to the presence of mast cells. Nonetheless, Andrade \& Andrade $^{8}$ stressed that the pathogenesis of diffuse interstitial fibrosis had not been clarified.

Quantitative studies made on cardiopathic Chagas' disease patients ${ }^{7}$ and on the circular esophagus musculature of chronic Chagas patients without megaesophagus ${ }^{11}$, have reported a marked increase in the mast cell count in these organs. However, no

\footnotetext{
1. Disciplina de Patologia Especial e Curso de Pós-Graduação em Patologia da Faculdade de Medicina do Triângulo Mineiro, Uberaba, MG

Financial support: FAPEMIG (project $n^{\circ}$. CDS - 2835/98) and CNPq.

Address to: Dra Sheila Jorge Adad. R. Getúlio Guaritá 130, 38025-440 Uberaba, MG.

Tel: 5534 3318-5152, Fax: 5534 3318-5846

e-mail:pe_fmtm@mednet.com.br

Recebido para publicação em 25/10/2002

Aceito em 6/6/2003
} 
statistical difference has been detected between the mast cell counts in the musculature of the esophagus ${ }^{5}$ and colon ${ }^{4}$ of chronic Chagas patients with and without megas, in relation to non-Chagas patients.

With regard to experimental Chagas' disease, there has been a report of increased mast cell count in areas of reinoculation with Trypanosoma cruzi on the skin of mice $^{10}$. Increased mast cell count has also been found in the submucosa and especially the musculature of the small and large intestines of mice chronically infected with the $A B C$ strain of $T$. cruzi ${ }^{14}$. Chapadeiro et $\mathrm{al}^{9}$ reported that, in albino Wistar rats infected experimentally with $T$. cruzi, mast cells were absent or rare in the infected animals in the acute phase.
Pinheiro et $\mathrm{al}^{12}$ demonstrated in rats chronically infected with $T$. cruzi that there was an increased mast cell count in the myocardium, although no relationship with fibrosis could be shown.

The data regarding the increase in mast cell count is controversial and there is a lack of morphometric studies on fibrosis in the musculature of the digestive tract of chronic Chagas patients. In view of this, we have made a morphometric evaluation of the fibrosis and mast cell count in the circular colon musculature of chronic Chagas patients with and without megas. Our objective was to gain better understanding of Chagas megacolon morphology and contribute towards the knowledge of fibrosis pathogenesis in megas.

\section{MATERIAL AND METHODS}

It was necessary that two of the three following tests were positive in the serum or in the pericardial fluid for the diagnostic of infection with Trypanosoma cruzi: ELISA (Enzyme-Linked-Immunosorbent-Assay), passive hemagglutination and indirect immunofluorescence to $T$. cruzi. The individuals of the control groups had the three tests negative.

Forty-five segments of large intestine were obtained via surgery and/or necropsy performed in the Pathology Service of the University Hospital of FMTM, Uberaba, Minas Gerais. Of these 45 cases, 30 individuals were chronic Chagas patients and 15 were non-Chagas patients without any intestinal pathology, who served as controls. The 30 Chagas patients were subdivided into two groups: with megacolon, consisting of 15 individuals, and without megacolon, also consisting of 15 cases.

In each case, a ring of around $0.5 \mathrm{~cm}$ in height was removed from the rectosigmoid transition. The rings were fixed in $4 \%$ formol and, after fixing, dehydrated, diaphanized and embedded in paraffin to form blocks measuring up to $5 \times 5 \mathrm{~cm}$ for microtomy. Histological sections with $7 \mathrm{~mm}$ in thickness were cut and stained using hematoxylin-eosin, Azan-Heidenhain and Giemsa techniques. The sections stained using the hematoxylin-eosin were only utilized for a general analysis of the rings. Following this, a quantitative analysis of the fibrosis was made on the sections stained using the Azan-Heidenhain technique and an counting of the mast cells on sections stained using the Giemsa technique.

The count of mast cells in the circular musculature was done using an standard optical microscope coupled to a video camera linked to a high-resolution monitor. The image obtained on the monitor was integrated with a cursor that could move across a graphical measuring grid connected to an automatic image analysis system of Leica Q 500MC brand. The count was done manually, while the area that was being evaluated was standardized.

The histological sections were previously marked at eight locations that were approximately equidistant from each other. The mast cells were counted in 40 consecutive fields of each subdivision, making a total of 320 microscope fields with the 10x eyepiece and $40 \mathrm{x}$ objective lens, corresponding to a total area of $4 \mathrm{~mm}^{2}$.

For the analysis of the fibrosis, the histological sections were again previously marked at eight locations that were approximately equidistant between each other. The fibrosis was measured in 10 alternate fields in each subdivision, making a total of 80 microscope fields covering a total area of $1 \mathrm{~mm}^{2}$. This analysis was also done with the 10x eyepiece and 40x objective lens. The same morphometry apparatus was utilized as described for the mast cell analysis (Figures 1A, 1B and 1C).

The variables analyzed were submitted to statistical analysis via the Kruskal-Wallis and Dunn tests. The significance level considered for the tests was $5 \%(p<0.05)$. To evaluate whether there was a relationship between the fibrosis percentage and the mast cell count, the Spearman test was utilized.

This research was approved by the Research Ethics Committee of Faculdade de Medicina do Triângulo Mineiro (FMTM), Uberaba, Minas Gerais.

\section{RESULTS}

The mast cells were found to be dispersed over the whole muscle tunica in all groups, generally without forming accumulations (Figures $2 \mathrm{~A}$ and $2 \mathrm{~B}$ ). In the megacolon group there were mast cells both at the myositis foci (Figure 2D) and dispersed over the remainder of the musculature (Figure $2 \mathrm{C}$ ).
In the non-Chagas group, no myositis was identified. In the Chagas group without megacolon, discrete myositis was found in four cases (30.1\%) (nos. 17, 20, 22 and 23). In the megacolon group there was myositis in 14 of the 15 cases $(93.3 \%)$, which was discrete in one case ( $\left.n^{\circ} 39\right)$, moderate in 6 cases 


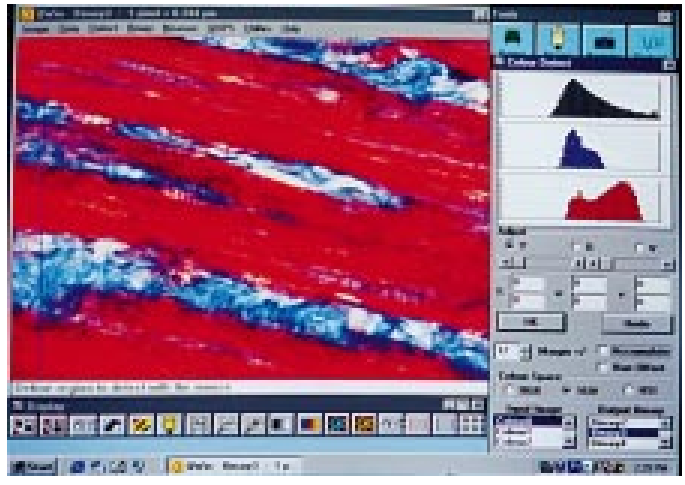

A

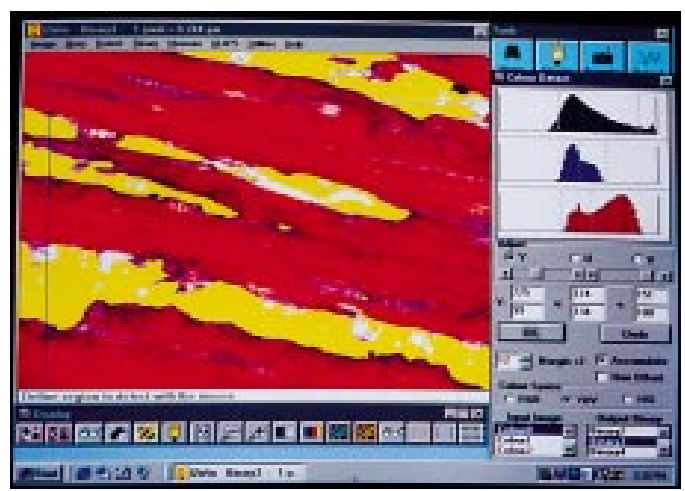

B

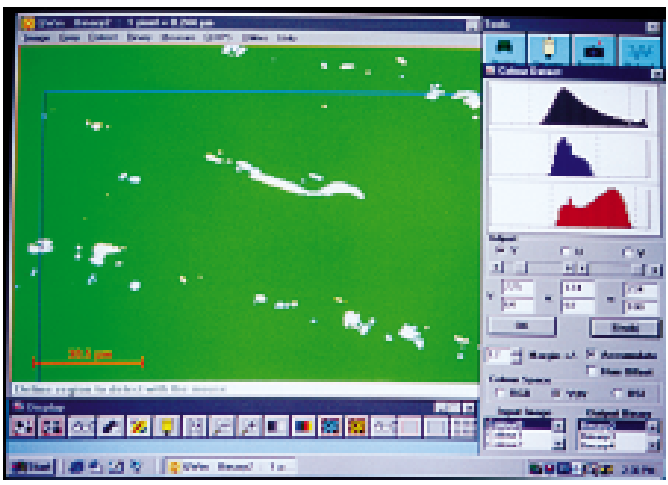

C

Figure 1- Image from the morphometry apparatus monitor, captured for quantitative evaluation of the fibrosis. In $A$, the original image, the muscle tunic of a Chagas case with megacolon is stained using the AzanHeidenhain technique (objective 40x): the muscle appears in red and the fibrous connective tissue in blue. In $B$, the marking of the fibrosis for automatic measurement can be seen, now in yellow. Next, as shown in $C$, the muscle is marked, excluding the empty areas that appear in white.
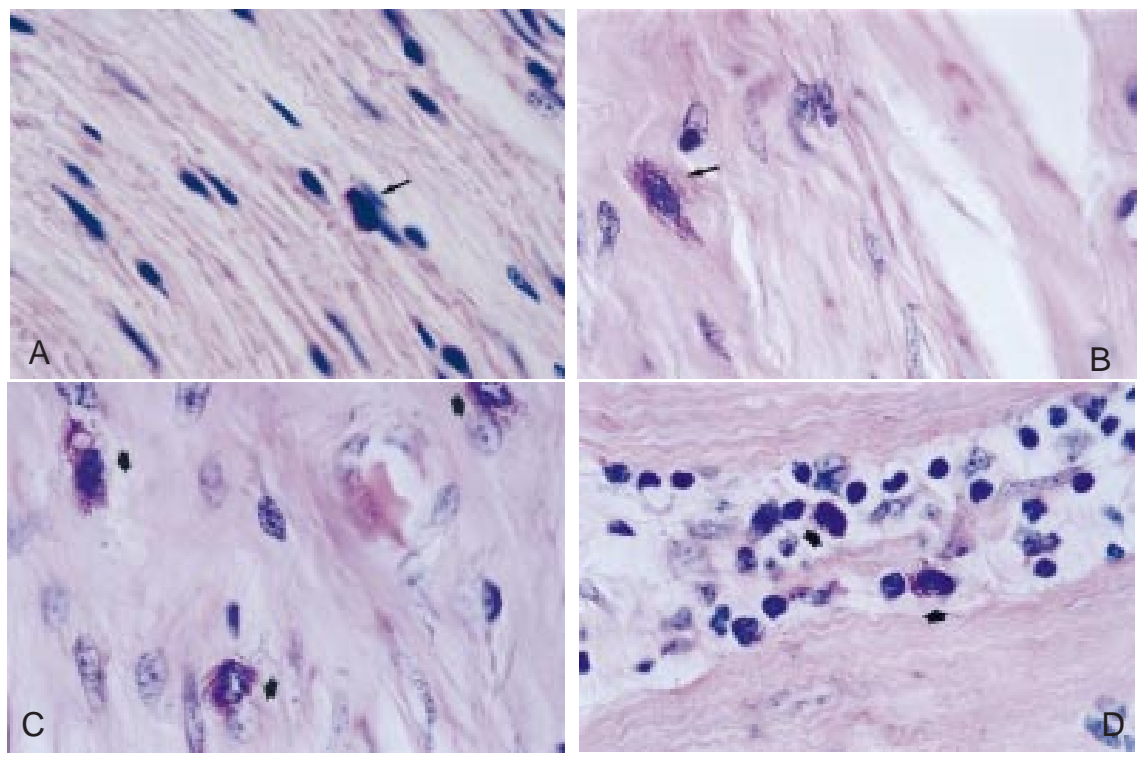

Figure 2 - In A, circular musculature of the rectosigmoid transition of a non-Chagas individual, in which a mast cell is observed (arrow). In B, musculature of a Chagas case without megacolon, in which a mast cell can also be seen (arrow). In C, muscle tunic of a Chagas case with megacolon, in which three dispersed mast cells can be seen (arrows). In D, myositis focus in a Chagas case with megacolon, in which two mast cells can be seen (arrows). Giemsa staining - objective 100x. 
(№s 31, 38, 42, 43, 44 and 45) and severe in 7 cases (nos 32, 33, 34, 35, 36, 37 and 40).

As indicated in Table 1, the mast cell count found in the circular colon musculature was significantly greater in the Chagas group with megacolon than in the other groups. When pairs of groups were analyzed Table 1 - Average values for mast cell counts in the circular colon musculature, according to the study group.

\begin{tabular}{lccc}
\hline & \multicolumn{3}{c}{ Chagas cases } \\
\cline { 2 - 4 } Mast cells & non & $\begin{array}{c}\text { without } \\
\text { megacolon }\end{array}$ & $\begin{array}{c}\text { with } \\
\text { megacolon }\end{array}$ \\
\hline Mean & 4.3 & 6.4 & 32.7 \\
Standard deviation & 5.9 & 10.7 & 32.1 \\
Median & 1.0 & 1.0 & 26.0 \\
Maximum value & 19 & 39 & 105 \\
Minimum value & 0 & 0 & 0 \\
No. of cases & 15 & 15 & 15 \\
\hline
\end{tabular}

Kruskal-Wallis test: $p=0.0016$. Dunn test: non-Chagas vs. Chagas without megacolon $p>0.05$; non-Chagas vs Chagas with megacolon $p<0.01$; Chagas without megacolon vs. Chagas with megacolon $p<0.01$. together, it was noted that the mast cell count was greater in the Chagas group with megacolon in comparison with the Chagas group without megacolon $(p<0.01)$ and the non-Chagas group $(p<0.01)$. However, there was no significant difference between the non-Chagas group and the Chagas group without megacolon ( $p>0.05$ ).

With regard to fibrosis, fibrous connective tissue in the muscle tunica was rare in the non-Chagas group and was represented by thin bands between the myocells (endomysial connective tissue) and between the muscle bundles (perimysial connective tissue) (Figure 3A).

In the Chagas group without megacolon, the appearance of the connective tissue in the muscle tunica was similar to that described for the non-Chagas individuals (Figure 3B). In the Chagas group with megacolon, there was an evident diffuse increase in endomysial and perimysial connective tissue and frequent substitution fibrosis foci (Figures $3 \mathrm{C}$ and $3 \mathrm{D}$ ).
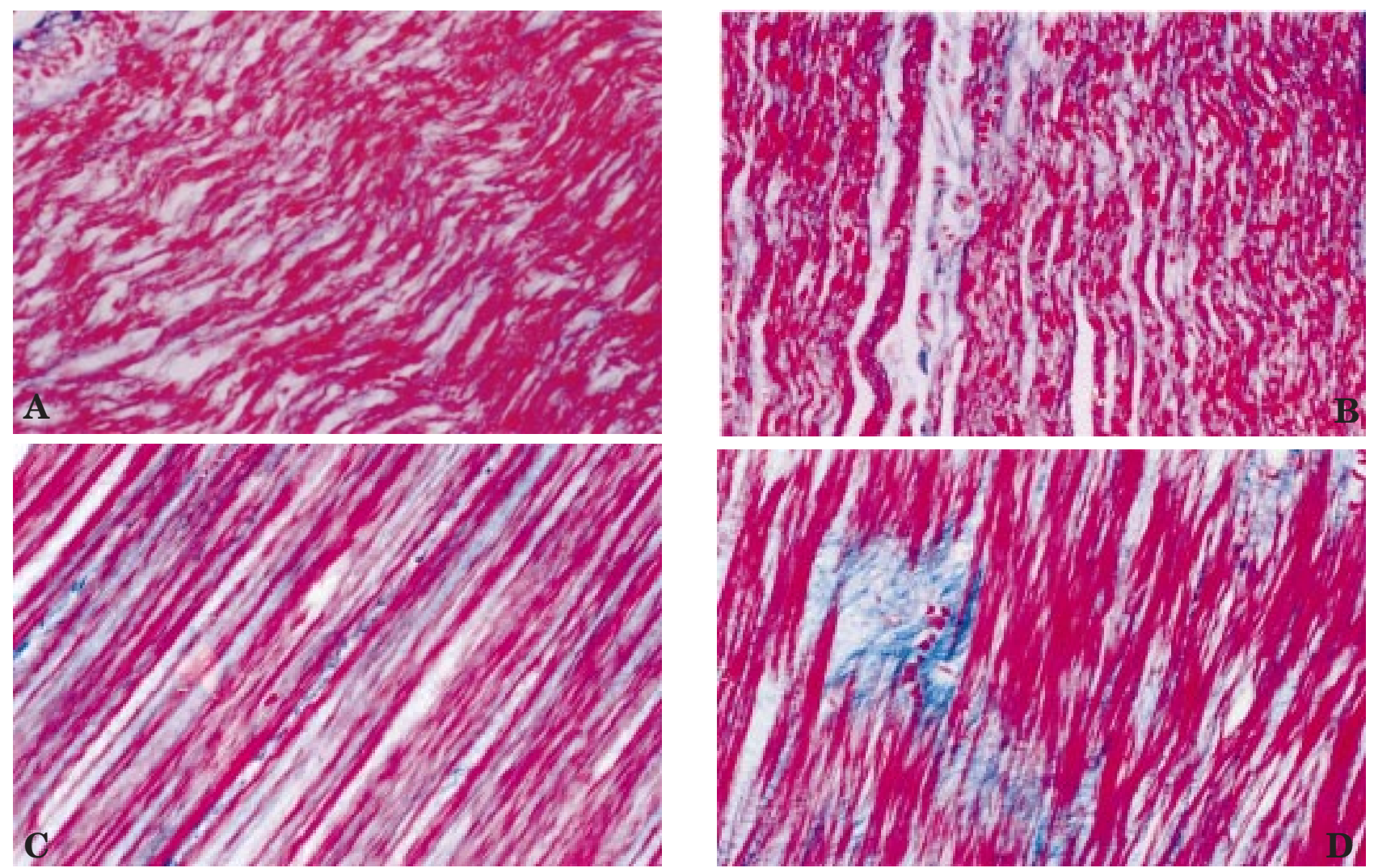

Figure 3 - In A, circular musculature of the rectosigmoid transition of a non-Chagas individual, in which rare fibrous connective tissue can be seen (stained blue). In B, musculature of a Chagas case without megacolon with an appearance that is similar to the nonChagas group. In C. Circular colon musculature of a Chagas case with megacolon, showing diffuse increased endomysial connective tissue (stained blue). In D, focal fibrosis interrupting and substituting muscle fibers, and also showing increased endomysial connective tissue in the colon musculature of a Chagas case with megacolon. Azan-Heidenhain staining - objective 40x. 
As can be seen in Table 2, there was a statistically significant difference between the groups. The percentage of fibrous connective tissue was greater in the megacolon group, in comparison with the Chagas group without megacolon $(p<0.001)$ and the nonChagas group $(p<0.001)$. However, there was no statistically significant difference between the nonChagas group and the Chagas group without megacolon $(p>0.05)$.

Table 2 - Average values for percentages of fibrous connective tissue in the circular colon musculature, according to the study group.

\begin{tabular}{lccc}
\hline & \multicolumn{3}{c}{ Chagas cases } \\
\cline { 2 - 4 } Fibrosis & $\begin{array}{c}\text { Non } \\
\text { Chagas cases }\end{array}$ & $\begin{array}{c}\text { without } \\
\text { megacolon }\end{array}$ & $\begin{array}{c}\text { with } \\
\text { megacolon }\end{array}$ \\
\hline Mean & 0.19 & 0.35 & 3.53 \\
Standard deviation & 0.15 & 0.20 & 1.73 \\
Median & 0.16 & 0.35 & 4.03 \\
Maximum value & 0.53 & 0.67 & 6.15 \\
Minimum value & 0.01 & 0.04 & 0.95 \\
No of cases & 15 & 15 & 15
\end{tabular}

Kruskal-Wallis test: $p<0.0001$. Dunn test: non-Chagas vs Chagas without megacolon $p>0.05$; non-Chagas vs Chagas with megacolon $p<0.001$; Chagas without megacolon vs Chagas with megacolon $p<0.001$.

Tables 3, 4 and 5 show the mast cells counting percentage of fibrous conjunctive tissue and myositis in the three groups studied.

The value for the Spearman correlation coefficient between the mast cell count and the percentage of fibrous connective tissue for the Chagas group with megacolon was -0.2 , which was not statistically significant $(p>0.05)$. However, when we analyzed the Chagas groups with and without megacolon together, the value for the correlation coefficient between the mast cell count and the percentage of fibrous connective tissue was 0.215 , which was statistically significant $(p<0.05)$, (Table 3,4 and 5).

Table 3 - Distribution of the non-Chagas cases according to mast cell count, percentage of fibrous connective tissue and myositis in the colon.

\begin{tabular}{lccc}
\hline Case & Mast cells & Connective tissue (\%) & Myositis \\
\hline 1 & 19 & 0.24 & - \\
2 & 3 & 0.16 & - \\
3 & 0 & 0.31 & - \\
4 & 5 & 0.24 & - \\
5 & 0 & 0.16 & - \\
6 & 0 & 0.16 & - \\
7 & 5 & 0.53 & - \\
8 & 0 & 0.23 & - \\
9 & 0 & 0.04 & - \\
10 & 1 & 0.08 & - \\
11 & 0 & 0.04 & - \\
12 & 0 & 0.05 & - \\
13 & 13 & 0.21 & - \\
14 & 11 & 0.01 & - \\
15 & 7 & 0.46 & - \\
\hline
\end{tabular}

Myositis: - absent
Table 4 - Distribution of the Chagas without megacolon cases according to mast cell count, percentage of fibrous connective tissue and myositis in the colon.

\begin{tabular}{lccc}
\hline Case & Mast cells & Connective tissue (\%) & Myositis \\
\hline 16 & 4 & 0.53 & - \\
17 & 18 & 0.35 & + \\
18 & 0 & 0.22 & - \\
19 & 1 & 0.13 & - \\
20 & 13 & 0.14 & + \\
21 & 1 & 0.67 & - \\
22 & 0 & 0.12 & + \\
23 & 0 & 0.28 & + \\
24 & 0 & 0.04 & - \\
25 & 7 & 0.33 & - \\
26 & 0 & 0.41 & - \\
27 & 39 & 0.54 & - \\
28 & 12 & 0.58 & - \\
29 & 1 & 0.39 & - \\
30 & 0 & 0.59 & \\
\hline
\end{tabular}

Myositis: - absent; + discrete

Table 5 - Distribution of the Chagas with megacolon cases according to mast cell count, percentage of fibrous connective tissue and myositis in the colon.

\begin{tabular}{lccc}
\hline Case & Mast cells & Connective tissue (\%) & Myositis \\
\hline 31 & 7 & 4.36 & ++ \\
32 & 28 & 2.57 & +++ \\
33 & 63 & 4.40 & +++ \\
34 & 51 & 5.04 & +++ \\
35 & 441 & 6.15 & +++ \\
36 & 34 & 4.08 & +++ \\
37 & 0 & 4.37 & +++ \\
38 & 24 & 4.03 & ++ \\
39 & 2 & 1.64 & + \\
40 & 3 & 4.03 & +++ \\
41 & 26 & 0.98 & - \\
42 & 105 & 1.21 & + \\
43 & 1 & 6.07 & + \\
44 & 18 & 3.03 & + \\
45 & 87 & 0.95 & + \\
\hline
\end{tabular}

Myositis: - absent; + discrete; ++ moderate; +++ severe

\section{DISCUSSION}

Our data are in agreement with quantitative studies of mast cells in the human myocardium ${ }^{7}$ and in the myocardium of rats with chronic Chagas' disease via experimental infection ${ }^{12}$. The data also agree with the description of increased mast cell counts in the circular musculature of the small and large intestines in mice with chronic Trypanosoma cruzi infection ${ }^{14}$.

Our data disagree with the quantitative studies made by Adad et $\mathrm{al}^{45}$ on the circular musculature of the esophagus and colon of chronic Chagas cases with or without megas. It is possible that these authors did not find significant differences between the groups because they analyzed a lesser number of microscope fields and cases. 
With regard to the results from counting mast cells in the musculature of the esophagus of chronic Chagas cases obtained by Pereira et $\mathrm{al}^{11}$, they appear at first to agree with those obtained in our study. However, those authors only evaluated the esophagus of Chagas cases without megas. In our material, we only observed a statistically significant difference in the group with megacolon, while the Chagas cases without megacolon did not present any significant difference when compared with the non-Chagas patients. We must stress that those authors worked with a greater number of cases and, in addition to this, there may be differences between how the esophagus and colon musculatures are compromised. It has already been demonstrated that myositis occurs more frequently and severely in the esophagus than in the colon of chronic Chagas cases ${ }^{6}$.

With regard to the morphometric analysis of fibrosis that was done in this study, we demonstrated that in the colon musculature there was a greater percentage of fibrous connective tissue in the Chagas group with megacolon, in comparison with the Chagas group without megacolon and the non-Chagas group. We did not find in the literature any morphometric studies of fibrosis in the colon of Chagas cases. Nonetheless, our findings are in agreement with the observations of $\mathrm{Adad}^{2}$, who described fibrosis in the muscle tunica of Chagas megacolon that was often moderate to severe, and also with the ultrastructural megaesophagus data of Tafuri et $\mathrm{al}^{15}$ and Tafuri ${ }^{13}$.

Our results appear to support the hypothesis that interstitial fibrosis is related to the mastocytosis present in experimental and human Chagas' disease, since we found greater mast cell counts in the muscle tunica of the group with megacolon, in relation to the others. Nevertheless, when we analyzed each group of Chagas cases separately, it was not possible to demonstrate a relationship between mast cells and fibrosis, perhaps because of the small number of cases. However, when we analyzed the Chagas groups with and without megacolon together, we observed a significant relationship between the mast cell count and the percentage of fibrous connective tissue.

In conclusion, the analysis of the findings of this study and the data in the literature demonstrate that there is a greater mast cell count and more fibrosis in Chagas cases with megacolon. However, it was not possible to demonstrate whether there is a relationship between the fibrosis and the mast cell count, as suggested by some data in the literature, perhaps because of the sample size.

\section{REFERENCES}

1. Adad SJ. Contribuição ao estudo da anatomia patológica e da patogênese do megaesôfago chagásico. Tese de Mestrado, Faculdade de Medicina do Triângulo Mineiro, Uberaba, MG, 1989.

2. Adad SJ. Contribuição ao estudo da anatomia patológica e da patogênese do megacólon chagásico. Tese de Doutorado, Faculdade de Medicina do Triângulo Mineiro, Uberaba, MG, 1996.

3. Adad SJ, Andrade DCS, Lopes ER, Chapadeiro E. Contribuição ao estudo da anatomia patológica do megaesôfago chagásico. Revista do Instituto de Medicina Tropical de São Paulo 33:445450, 1991.

4. Adad SJ, Lazo JEC, Rua AMO, Duarte R, Teixeira VPA. Contagem de mastócitos na muscular do cólon de chagásicos crônicos com e sem megacólon. In: Anais do XXI Congresso Brasileiro de Patologia, Brasília p.33, 1997.

5. Adad SJ, Resende AV, Jorge BH. Estudo sistematizado do plexo mientérico nos diferentes terços do esôfago de chagásicos crônicos com e sem megaesôfago. Revista da Sociedade Brasileira de Medicina Tropical 25 (supl III): 101, 1992.

6. Adad SJ, Souza Neto AH, Pinheiro SW, Araújo JR, Lopes ER. Avaliação quantitativa e qualitativa do processo inflamatório no coração e tubo digestivo de chagásicos crônicos. Revista da Sociedade Brasileira de Medicina Tropical 33(supl II): 107, 2000.

7. Almeida SC, Pereira FEL, Tafuri WL. Estudo quantitativo dos mastócitos na cardiopatia chagásica crônica. Revista do Instituto de Medicina Tropical de São Paulo 17: 5-9, 1975.

8. Andrade ZA, Andrade SG. Patologia. In: Brener Z, Andrade ZA, Barral-Neto M. Trypanosoma cruzi e doença de Chagas. Guanabara Koogan, Rio de Janeiro, p.177-226, 2000.
9. Chapadeiro E, Beraldo PSS, Jesus PC, Oliveira Jr, WP, Junqueira Jr LF. Lesões cardíacas em ratos Wistar inoculados com diferentes cepas do Trypanosoma cruzi. Revista da Sociedade Brasileira de Medicina Tropical 21: 95-103, 1988.

10. Menezes H, Alcântara FG. Os mastócitos da pele de camundongos infectados experimentalmente com Trypanosoma cruzi. O Hospital 68: 187-190, 1965

11. Pereira FEL. Estudo quantitativo dos mastócitos na musculatura do esôfago de chagásicos crônicos. Revista do Instituto de Medicina Tropical de São Paulo 14: 30-32, 1972.

12. Pinheiro MCN, Beraldo PSS, Júnior LFJ, Lopes ER, Chapadeiro E. Análise quantitativa de mastócitos de ratos Wistar cronicamente infectados pelo Trypanosoma cruzi. Contribuição ao conhecimento da fibrose miocárdica. Revista da Sociedade Brasileira de Medicina Tropical 25: 45-50, 1992.

13. Tafuri WL. Alterações ultra-estruturais dos componentes muscular, intersticial e nervoso do coração e intestinos na doença de Chagas experimental e humana. Tese de Professor Titular. Faculdade de Medicina, Universidade Federal de Minas Gerais, Belo Horizonte, MG, 1974.

14. Tafuri WL, Brener Z. Lesões do sistema autônomo do camundongo albino na tripanosomíase cruzi experimental, na fase aguda. O Hospital 69: 179-191, 1967.

15. Tafuri WL, Maria TA, Lopes ER. Lesões do plexo mientérico do esôfago, do jejuno e do colo de chagásicos crônicos. Revista do Instituto de Medicina Tropical de São Paulo 13: 76-91, 1971.

16. Tafuri WL, Raso P. Anatomia Patológica. In: Raia AA (eds) Manifestações digestivas da moléstia de Chagas. São Paulo: Sarvier, p.61-79, 1983. 